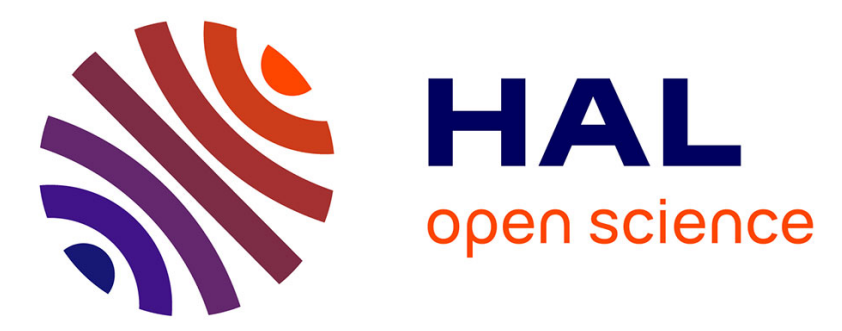

\title{
Spatial and temporal factors of erosion by water of black marls in the badlands of the French southern Alps \\ Luc Descroix, Jean-Claude Olivry
}

\section{To cite this version:}

Luc Descroix, Jean-Claude Olivry. Spatial and temporal factors of erosion by water of black marls in the badlands of the French southern Alps. Hydrological Sciences Journal, 2002, 47, $10.1080 / 02626660209492926$. ird-02157747

\section{HAL Id: ird-02157747 \\ https://hal.ird.fr/ird-02157747}

Submitted on 17 Jun 2019

HAL is a multi-disciplinary open access archive for the deposit and dissemination of scientific research documents, whether they are published or not. The documents may come from teaching and research institutions in France or abroad, or from public or private research centers.
L'archive ouverte pluridisciplinaire HAL, est destinée au dépôt et à la diffusion de documents scientifiques de niveau recherche, publiés ou non, émanant des établissements d'enseignement et de recherche français ou étrangers, des laboratoires publics ou privés. 


\title{
Spatial and temporal factors of erosion by water of black marls in the badlands of the French southern Alps
}

\author{
LUC DESCROIX \\ Institut de Recherche pour le Développement (IRD), Laboratoire d'étude des Transferts en \\ Hydrologie et Environnement, UMR 5564, BP 53, F-38041 Grenoble cedex 9, France \\ descroix@hmg.inpg.fr
}

JEAN-CLAUDE OLIVRY

IRD, BP 5045, F- 34032 Montpellier cedex, France

jean-claude.olivry@,wanadoo.fr

\begin{abstract}
Jurassic black marls constitute one of the most extensive outcrops in the Alpine massif. They include the most eroded terrains in the French Alps. Black marls are subject to strong weathering and their erosion rate can reach values close to $1 \mathrm{~cm}$ year $^{-1}$ (i.e. $100 \mathrm{~m}^{3} \mathrm{ha}^{-1}$ year $^{-1}$ ). Many studies have focused on the processes and forms of erosion of these black marls and on the development of an original metrology to improve our understanding of the seasonal processes in these badlands areas. This study shows that alternating freeze-thaw and wet-dry cycles are the main causes of disaggregation in the marls. The exposure of hillslopes and the dip-slope angle are the main site factors explaining the variability in the action of these processes and thus, in the soil thickness lost as a result of erosion. The kinetic energy of rainfall is similar everywhere, but the volumes of regolith transported by runoff depend on the effects of previous weathering.

Key words black marls; badlands; southern French Alps; erosion factors; exposure

Facteurs spatiaux et temporels de l'érosion hydrique des badlands de marnes noires des Alpes françaises du Sud

Résumé Les marnes noires de l'Oxfordo-Callovien et du Bathonien supérieur constituent l'un des affleurements les plus étendus des Alpes. On y trouve les terrains les plus érodés des montagnes françaises. Les marnes noires sont fortement soumises à la désagrégation et l'ablation annuelle y représente une lame d'ordre centimétrique $\left(100 \mathrm{~m}^{3} \mathrm{ha}^{-1} \mathrm{an}^{-1}\right)$. De nombreux travaux ont analysé les processus et les formes de l'érosion des marnes noires et se sont intéressé à une métrologie originale afin de cerner le comportement des badlands. On montre que les alternances gel-dégel et humectation-dessiccation sont les principales causes de la désagrégation des marnes. L'exposition des versants et l'angle constitué par la pente et le pendage des couches sont les facteurs primordiaux d'explication de la variabilité de l'action de ces processus et donc de la lame érodée. L'énergie cinétique des pluies est la même partout, mais le volume de régolites à transporter dépend de l'efficacité préalable de la désagrégation.
\end{abstract}

Mots clefs marnes noires; badlands; Alpes françaises du Sud; facteurs d'érosion; exposition

\section{INTRODUCTION}

The Southern pre-Alps are known for their widespread badlands. Most of them correspond to the famous "terres noires", black marls of the Bajocian, Bathonian, Oxfordian and Callovian stages, and other types of marls, including the "blue marls" of the Cenomanian. They constitute one of the most significant degraded areas in Europe. 


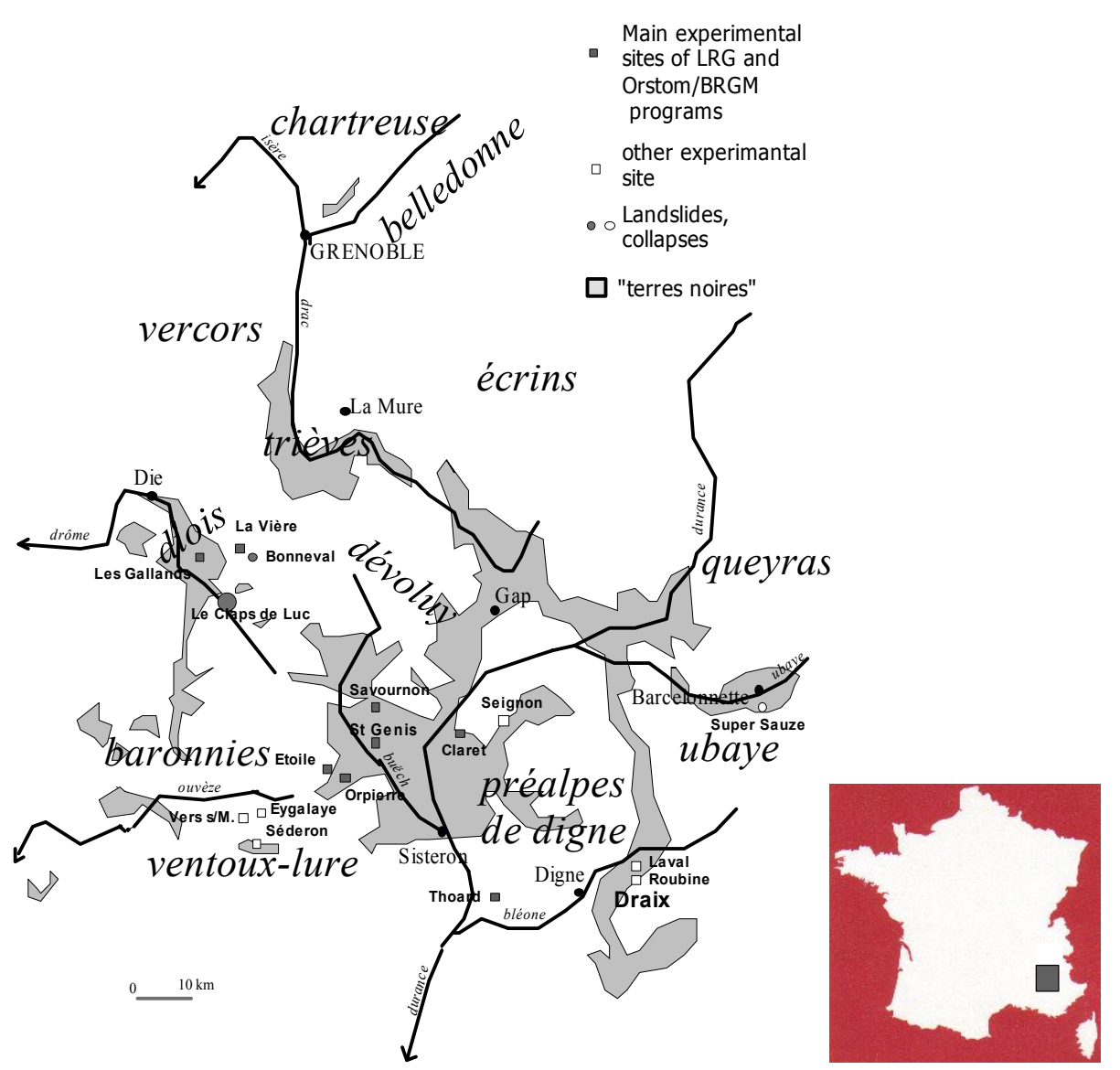

Fig. 1 Location of the "terres noires" areas in the French Alps.

These badlands are mostly located within the boundaries of the "Vocontian Graben", a Jurassic sea which corresponds to the actual massifs of the Diois, Baronnies, Préalpes de Digne and the middle-Durance basin (Gapençais, Laragne and Aspres domes, St-Genis and Barcillonnette massifs) (Fig. 1). The thickness of the marls deposited in this "graben" averages $1500 \mathrm{~m}$ and locally reaches $2000 \mathrm{~m}$.

Nowadays, badlands are present throughout the entire alpine range, but the black marl badlands are mostly found in the previously described areas (Fig. 1). They are a significant sediment source for the southern alpine rivers. Being the largest degraded area in the Alps and at the same time an homogeneous outcrop (Artru, 1972), they constitute an interesting experimental area for the study of erosion in the mountains. These outcrops have been severely eroded and the badlands constitute a great proportion of the total area. Both the extensive coverage of the badlands and their homogeneous lithology facilitate the specification of all the different local conditions necessary to study the site variables. It is perhaps the reason why significant research into mountain erosion has been carried out in this kind of "natural laboratory". The following list presents some of the most important studies. Erosion rates are preferentially expressed herein as soil depth loss in $\mathrm{mm}_{\text {year }}{ }^{-1}$, because the measurements were frequently carried out at point and micro-plot scales; therefore it would be inaccurate to extrapolate the data to larger areas.

- In the case of the small Seignon catchment (Préalpes de Digne), Combes (1981) calculated soil losses in the "terres noires" as the ratio of the volume of sediments 
trapped in a small reservoir divided by the eroded area of the catchment. The calculated rate averaged $7 \mathrm{~mm}$ year ${ }^{-1}$ over 18 years.

- Site and rainfall variables were the subject of research carried out by the Laboratoire Rhodanien de Géomorphologie (LRG, CNRS-Lyon II, France) from 1981 to 1992 in the Baronnies, Diois and Préalpes de Digne regions (Descroix, 1985, 1994). The results are presented subsequently in this paper.

- The Draix experimental catchment (Préalpes de Digne) was set up by Cemagref (France) in 1983 and it remains the main research site in France for mountain erosion (Cemagref, 1987, 1995, 1997; Mathys et al., 1996). The most notable results are an erosion rate of 6-8 $\mathrm{mm}_{\text {year }}{ }^{-1}$ and the determination of the essential role of extreme rainfall events in the generation of erosion and runoff.

- Between 1984 and 1992, both Orstom and the Bureau de Recherches Géologiques et Minières (BRGM) developed new methodologies on three catchments in the Buëch Valley (Olivry et al., 1988; Bufalo, 1989; Olivry \& Hoorelbeck 1990); the Laboratoire Rhodanien de Géomorphologie (Descroix, 1994) joined this team in 1985. The results are also presented later in this paper.

- A Parisian team (Université Paris VI) measured soil losses on black marls and studied their variables in the upper Méouge Valley (Baronnies) (Chodzko et al., 1991; Lhénaff et al., 1993; Lecompte et al., 1996). They measured soil loss rates in black marls of 30-35 mm year ${ }^{-1}\left(300-350 \mathrm{~m}^{3} \mathrm{ha}^{-1} \mathrm{year}^{-1}\right)$.

- Oostwoud Widjenes \& Ergenzinger (1998) used a rainfall simulator to create and study miniature debris flows on eroded slopes of the Draix experimental catchment. They obtained data on the generation of debris flows and the determination of climatic factors influencing them.

- Since 1997, a scientific group from the Institut de Géographie Alpine (Grenoble, France) has conducted studies on soil losses in black marls in the Seignon catchment (Robert, 1997; Rovera et al., 1999b). They confirmed the soil loss rates found by in the same catchment Combes (1981).

Bibliographic reviews have already been made by Olivry \& Hoorelbeck (1990) and by Delannoy \& Rovéra (1996) in a special issue of the Revue de Géographie Alpine (RGA, 1996). Nevertheless, the results had been obtained from several sites and at specific times, which did not allow the distinction between site-specific processes and factors to be made. The present research is the first to have been carried out at several sites simultaneously (10 sites in 4 sub-regions).

The aim of this paper is to synthesize the results obtained in four study areas (the Diois, the Baronnies, the Buëch Valley and the Préalpes de Digne) over a period of ten years, allowing regional processes and factors to be distinguished from local ones. Thereafter, the main objective is to explain the levels of soil losses on black marl badlands in terms of the spatial and temporal factors. The same devices used on black marls were adapted for the other, lithologically different southern-alpine terrains, allowing the comparison of results and the determination of processes specific to each kind of outcrop subject to active erosion (black marls, blue marls, moraines, molasses, clays).

Given the extensive areas of black marls within the four regions, the leading idea of this study was to consider that, as the substratum conditions were almost identical, the variation in erosion rates would be due to the variations in site-specific factors. In the following, a clear distinction is made between temporal and site-specific variables. 


\section{Temporal factors}

It is expected that a typology of explanatory variables for erosion in the "terres noires", from the detachment of soil particles to dam sedimentation, should be obtained from the numerous investigations.

Most authors of previous studies assigned considerable significance to climatic factors, particularly the actions and interactions of freeze-thaw and wet-dry cycles (Descroix, 1985; Deshons, 1985; Peyronnet, 1988; Olivry et al., 1988; Bufalo, 1989; Brochot \& Meunier, 1995). Rock is weathered during freeze-thaw cycles, which are effective only if the rock water content is consistent and if wet periods occur during the winter: rainfall and snowfall generally coincide with a rise in temperature, and a wetting front can reach a depth of tens of centimetres. There is a general consensus (confirmed also by Lecompte et al., 1998) that the year should be divided into two periods:

- the winter season, during which materials are acted on and detached by cryoclastism (rock disaggregation by the action of freeze-thaw cycles), and often transported by solifluction processes (soil slide due to the high water content); the rise in temperature in the spring results in the accumulation of material on slopes and at the bottoms of hillslopes.

- the summer, which is characterized by intensive and short rainfall events; the main morphogenic action is due to erosion by water: material detached during winter is removed by splash and transported by overland flow.

The seasonally contrasting action on badlands results in the presence of a regolith layer ranging in thickness from 1 to $5 \mathrm{~cm}$, referred to as "spangles" or "flakes" ("paillettes" in French) (Descroix, 1985; Olivry et al., 1988; Peyronnet, 1988; Oostwoud Widjenes \& Ergenzinger, 1998), above a 10-20 cm layer of rock fragments ("chips"), overlaying the bedrock which is fractured over the first $30-60 \mathrm{~cm}$ and made up of 10-40 cm thick blocks. A good description of weathered facies in the Draix marls has been made by Coulmeau (in Cemagref, 1987).

When the Laval station access path (Draix catchments) was dug in 1987, a collapse occurred and fallen blocks consisted of fresh rock (Descroix, 1994). Marl fracturing immediately follows the exposure of the bedrock, as seen in fresh outcrops caused by collapses or landslides. Collapses are relatively frequent in the "terres noires" due to the steepness of the badlands slopes $\left(30-45^{\circ}\right)$. According to Brochot \& Meunier (1995), the high porosity of the marls (6.8\% compared to $1.6 \%$ for limestone), schistosity, weak limestone content and high density of joints, all account for the rapid weathering of these areas. Malet et al. (2000) and Schmutz et al. (2000) observed that marl blocks which had collapsed 40 years ago in the region of Barcelonnette, and which were overlain by the landslide, remained intact until they outcropped; thereafter, they suffered rapid disaggregation due to wet-dry and freezethaw cycles. Lecompte et al. (1998) found that the high rates of soil loss are due to decompression as and when the superficial regolith layer is removed. However, rock weathering is more likely due to both the great porosity of the regolith layer and the effects of freeze-thaw cycles.

The number of freeze-thaw cycles during the year may be of the order of 100 or more. Freezing is estimated to affect the first 5 or $10 \mathrm{~cm}$ of soil and/or rock. Rovera et al. (1999a) demonstrated that the number of freeze-thaw cycles at $6 \mathrm{~cm}$ depth is significantly higher on north-facing slopes (called "ubac" in French) than on southfacing ("adret"): in the Seignon catchment, 83 cycles were measured at the soil surface 
for a relatively warm year; but at $6 \mathrm{~cm}$ depth, only 12 cycles were observed on a southfacing slope, while 41 cycles were recorded on a north-facing one. In their study in the Draix experimental catchments, Oostwoud Widjenes \& Ergenzinger (1998) described these processes, which are widespread on marly bare fields, as miniature debris flows (MDFs). At the same site, Brochot \& Meunier (1995) observed a "laminar solifluction" on south-facing slopes during winter, as a result of daily thaw. All these authors agree on the significance on marly slopes of processes, such as creeping (downslope movements due to wetting-drying cycles), cryo-creeping (movements due to freeze-thaw cycles) and cryoturbation (fragment sorting caused by freeze-thaw cycles, and leading to the formation of pipkrakes). Finally, Bufalo (1989) and Descroix (1994) described a process previously tackled by Birot (1981), namely that the freezing and wetting of the soil and/or regolith layer induces the field surface to rise parallel with the slope; thawing or desiccation leads to a vertical packing due to gravity: this results in a recurrent creeping of the regolith layer down slope.

The transportation of eroded particles down the slopes and out of the catchments is more straightforward. Strong intensities and high kinetic energy values of rainfall from the end of summer to the beginning of autumn are considered by most of the authors who have studied erosion at the scale of the rainfall event (Deshons, 1985; Descroix, 1985 and 1994; Olivry et al., 1988; Bufalo, 1989; Chodzko et al., 1991) to be the main variables accounting for transportation.

\section{Site variables}

Site variables include spatial factors of erosion, as opposed to event characteristics (mainly climatic variables). Several site configurations are taken into account, but the lithology is considered to be unchanged, due to the relative homogeneity of the black marl terrains. Hillslopes in the black marl badlands always have a gradient value between 30 and 45 (Deshons, 1985; Descroix, 1994; Lecompte et al., 1998). Thus, the slope value alone does not explain the variability of the erosion. The main explanatory factors of soil losses are the following:

Exposure In the Savournon and Saint Genis experimental catchments (Fig. 1), Deshons (1985) observed that the regolith surface layer is thicker on south-facing slopes, and this was attributed to a greater number of freeze-thaw cycles. On the other hand, it has been shown that freezing and freeze-thaw processes are more marked on north-facing slopes (Rovera et al., 1999a). Using experimental plots on the Savournon site, it has been shown that soil losses are always 3-5 times higher on north-facing slopes than on south-facing ones (Descroix, 1994). The number of wet-dry cycles is higher on south-facing slopes during the winter; it is probably on this basis that some authors considered mechanical weathering to be stronger on south-facing slopes. This suggests that there are discrete disaggregation and transportation processes. With the impact of rainfall being the same on all kinds of exposures, it can be concluded that processes due to freezing induce higher yields and transportation values on northfacing slopes than do rainfall events. In the Méouge valley, Chodzko et al. (1991) firstly measured higher values of soil losses on south-facing slopes; later however, it was concluded that exposure played no role in the erosion yield (Lecompte et al., 1998). Robert (1997) and Coubat (1998) emphasised the difference in processes in the 
Seignon catchment, with more disaggregation observed on south-facing slopes, and more solifluction processes on north-facing slopes. Blijenberg et al. (1996) and Oostwoud Widjenes \& Ergenzinger (1998) stressed the occurrence of debris flows and miniature debris flows on the north-facing slopes of black marl hills.

Slope-bedding dip angle As with northward and southward exposure, the angle between the slope and the bedding dip determines a contrast: those slopes parallel to the bedding are more resistant to weathering, but they are more exposed to the impact of solifluction processes (Deshons, 1985; Descroix, 1994). In contrast, the slopes approximately perpendicular to the bedding are more affected by weathering (the configuration being more favourable to the penetration of freezing and wetting fronts) and less exposed to solifluction (soil particles or rock fragments are retained on the slope and cannot creep). It was observed, on both black and blue marls, that the dipslope angle had no influence on values of soil losses (Descroix, 1994). In the Draix experimental catchment, Oostwoud Widjenes \& Ergenzinger (1998) demonstrated that there is a great difference between "miniature debris flows" on different hillslopes according to the perpendicularity or the parallelism of dip and slope. In the first case, the particles are smaller; in the latter, detached material is more readily transported due to the creeping of particles along the joints, and the particles are also bigger. These authors observed that bulk density is similar (between 1.5 and $1.8 \mathrm{~g} \mathrm{~cm}^{-3}$ ) in both cases, whereas the grain size distribution differs.

As the erosion processes are influenced by both the exposure and the dip-slope angle, the interpretation of the results is not straightforward. The conjunction of a north-facing slope and a perpendicular dip-slope angle seems to be the most yielding configuration. However, this configuration alone cannot account for all the differences between the rates of soil loss on two sides of a gully (Robert, 1997; Lecompte et al., 1998).

Position on the slope Most of the studies have shown that two main stages can be distinguished: a winter disaggregation phase and a summer transportation phase. Within this framework, the position on the slope also plays a major role. In the eastern Baronnies, the following contrasts were observed (Lecompte et al., 1996; Lecompte et al., 1998): (a) continuous erosion occurs on the interfluve areas; and (b) the lower parts of the slopes and the bottoms of gullies show an alternation between winter accumulation phases and summer transportation phases.

Among the other spatial variables, bare soil (absence of vegetation) is also known to be a main factor influencing erosion. It is both a cause and a consequence of the erosion, due to the difficulty in re-vegetating the badlands (Cemagref, 1995).

In spite of its commonly acknowledged significant impact on erosion values (Cohen, 1998; Lukey et al., 2000), vegetation cover has not been considered herein, given the overall lack of vegetation in the study area.

\section{MATERIALS AND METHODS}

The main field methods used were a micro-profile meter and a sediment trap, employed at plot, micro-catchment and catchment scales. The influence of freeze-thaw and wet-dry cycles on the rock structure was simulated using a climatic simulator. 


\section{Climatic simulator}

The effects of climatic cycles were reproduced (Descroix, 1985) by the climatic simulator at the Laboratoire Rhodanien de Géomorphologie (LRG, CNRS- Lyon II). Black and blue marl samples ( $7 \mathrm{~cm}$ edge cubes) were subjected to 100 daily freezethaw cycles. Every seven days, samples were also submitted to a wet-dry cycle, after which residual water remained in a small receptacle. The extreme temperatures of each freeze-thaw cycle were fixed at -15 and $+15^{\circ} \mathrm{C}$.

\section{Plots and catchments and their equipment}

For the analysis of soil losses and of the influence of spatio-temporal factors, a twofold experimental design was adopted.

The experimental plots were set up to determine the impact of rainfall on soil losses. Nineteen micro-plots ranging from 2 to $10 \mathrm{~m}^{2}$, were installed at six different sites very close to an electronic recording raingauge (Orstom-Elsyde type; Olivry \& Hoorelbeck, 1990), to analyse the influence of the following factors:

- rainfall intensity and effective rainfall; the latter is the rainfall which has caused runoff due to its intensity exceeding the soil infiltration capacity;

- rainfall kinetic energy;

- antecedent precipitation index $(A P I)$. Following the definition of the antecedent precipitation index (Kohler \& Linsley, 1951), $A P I_{n}$ is calculated as:

$$
A P I_{n}=\left(A P I_{n-1}+P_{n-1}\right) \exp (-\alpha \Delta t)
$$

where $\Delta t=t_{n}-t_{n-1}$ is the time (day and/or fraction of day) elapsed between the end of the previous rain event $P_{n-1}$ and the beginning of the current one $\left(P_{n}\right)$. The parameter $\alpha\left(\right.$ day $\left.^{-1}\right)$ is the inverse of the characteristic time of soil moisture depletion.

After each rainfall event, the total overland flow and suspended load, collected in a 200-1 barrel, were measured and statistically processed with the rainfall data. Depending on the site, 40-220 rainfall events were taken into account. The measuring period lasted between two and six years depending on the site.

At the micro-hillslope scale, a micro-profile meter (Olivry et al., 1988) (Fig. 2) was used to measure the annual erosion depth. It was adapted from Burwell et al. (1963), who called it a "microrelief meter", but was modified for use on steep slopes. Due to the precision of the device $(1 \mathrm{~mm})$ and the annual erosion depth (around $1 \mathrm{~cm}$ ), this method is effective only at yearly time scales. Difficulties related to cryo-ejection (the ejection by freeze-thaw cycles of devices installed in the soil) were resolved by the Orstom-BRGM-LRG team in the Savournon catchment. The device is mounted on fixed rods. Although the rods were driven $50 \mathrm{~cm}$ deep into the soil, it appeared that in the first year they were subject to cryo-ejection; some of them were exposed and ejected by the first cycles. Therefore, in a second stage, the rods were concreted in, and no more problems were registered in the next six years (Descroix, 1994). The microprofile meter is used only during the measurement while the rods stay in the field. Twenty-six pairs of fixed rods were installed at eight different sites.

At both the micro-catchment and the catchment scales, the sediment trap principle was adopted to estimate the erosion rate. Considering the small area of the study 


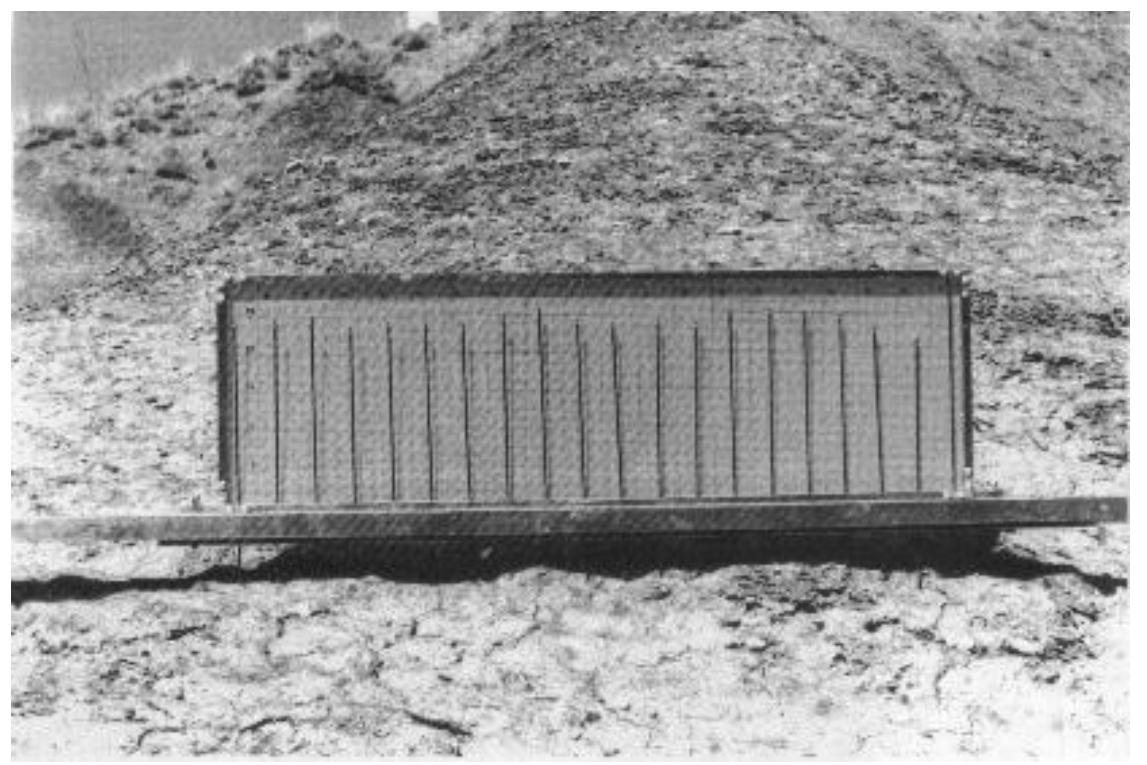

Fig. 2 Micro-profile meter in situ (SAVOURNON: built by J. Hoorelbeck \& $\mathrm{J}$. C. Olivry, Orstom). The measured area is $1 \mathrm{~m}$ long at each measurement point; there are several pairs of fixed rods on each site. The micro-profile meter is removed after each measurement.

catchments, fine detached particles are rare and most of the eroded material may be trapped. Sediment traps were installed in catchments ranging in size from $100 \mathrm{~m}^{2}$ to 80 ha. In the latter case, batteries of bottle-siphon samplers, which allow automatic sampling during the flows, were added to the device, in order to measure the suspended load of the flow leaving the trap.

\section{The Nazas model: an API-type model}

The superficial regolith layer of the black marls seems to have the same hydrological behaviour as a thin soil. No water table being hosted by the marls, the hillslopes have a Hortonian behaviour. However, the soil water content at the beginning of a rainfall event plays an important role in the functioning of the runoff process.

Obviously, erosion by water is the main erosional pattern; overland flow is the first factor responsible for particle transportation. This is why a rainfall-runoff model is used here to explain the effect of previous soil water content on erosion yield.

An API-type model already used in another experiment (Viramontes, 2000; Descroix et al., in press) was tested here to explain runoff formation on marly hillslope micro-plots.

\section{RESULTS}

It was found that the annual soil loss in marly badlands is around 7-10 $\mathrm{mm} \mathrm{year}^{-1}$. Under "normal" conditions, the values range from 5.9 to $11.7 \mathrm{~mm}_{\text {year" }}^{-1}$. Higher rates have been observed in the Gallands site, but the two-year observation period was strongly influenced by a rainfall event with a return period of approximately 10 years (100 $\mathrm{mm}$ in $2.5 \mathrm{~h}$ in July 1990). 
On the other types of lithology, the following soil loss rates were measured:

- $1.4 \mathrm{~mm}_{\text {year }}{ }^{-1}$ for molasses, commonly known to be porous and therefore not so erodible as marls;

- $16.5 \mathrm{~mm} \mathrm{year}^{-1}$ for glacial fields, famous for their original landforms called "cheminées de fées" or "demoiselles coiffées" and observable in all of the alpine massif, and most frequently in the southern French Alps. They are very often subject to the effects of torrential flows and thus experience severe erosion;

- the value attributed to Oligocene clays is only mentioned for comparison; its low representativity is due to both the lack of outcrops and the generally dense vegetation cover. However, it is worth noting the Bonneval mudflow, where a 28 ha deposit of this kind of material was exposed to rainfall, resulting in intense erosion.

\section{Spatial factors}

Exposure of the site On black marls at the sites in the Baronnies (Savournon, Saint Genis and Orpierre), it is shown that the erosion depth on north-facing slopes is greater (around $11.6 \mathrm{~mm}_{\text {year }}{ }^{-1}$ ) than on south-facing ones $\left(3.8-6.5 \mathrm{~mm}^{-1}\right.$ year $^{-1}$ ).

On the marls, it has been possible to compare different measurement techniques; erosion values are similar for all the methods. For example, on the Savournon and Saint Genis sites (black marl)and on the Etoile site (south-facing slope on blue marls), the micro-profile meter and the sediment traps gave similar results. Furthermore, on the Gallands site, results obtained both on plots and by micro-profile meter are comparable (16.2 and $18.5 \mathrm{~mm} \mathrm{year}^{-1}$, respectively). It is important to note that measurements with both methods were not made at exactly the same locations; however, the spatial homogeneity of marls makes this kind of comparison possible.

This spatial homogeneity can also be referred to when comparing soil loss values at different sites on the scale of the French southern Alps. All the results for the three black marl sites (Savournon, Saint-Genis, Orpierre) gave erosion values of between 5.9 and $9 \mathrm{~mm}$ year $^{-1}$, while only two of the sites located on the blue marls (Etoile and La Vière) can be compared and their results are also similar ( 8.6 and $\left.10.3 \mathrm{~mm}_{\text {year }}{ }^{-1}\right)$.

It is significant that the size of the considered area (points, microplots of $2-10 \mathrm{~m}^{2}$, micro-catchments or catchments) does not influence the rate of soil loss. As erosion rates are four or five orders of magnitude greater in eroded areas than in vegetated ones, the total sediment transported out of the watershed is considered as coming only from those areas of the catchment that are already eroded.

The rates of soil loss obtained in this study were compared with data measured by other authors, at other sites and with different methodologies. The values obtained are close to those given by:

- Combes (1981) for the Seignon catchment, based on the sediment filling of a reservoir over 20 years $\left(6.8 \mathrm{~mm}_{\text {year }}{ }^{-1}\right)$;

- Bufalo (1989), who measured an erosion depth of $11.5 \mathrm{~mm} \mathrm{year}^{-1}$ by trapping sediments on three micro-catchments at the Saint Genis experimental site.

- The Cemagref team for the Draix experimental catchments (11-12.1 mm year $\left.{ }^{-1}\right)$ (Cemagref, 1987, 1995, 1997); their main devices were traps;

- Chodzko et al. (1991) and Lecompte et al. (1996) for the blue marls of the upper Méouge river basin (7-8 $\left.\mathrm{mm}_{\text {year }}{ }^{-1}\right)$;

- Rovera et al. (1999b) in the Seignon catchment (4-10 $\left.\mathrm{mm} \mathrm{year}^{-1}\right)$; 
The only significantly different result is that of Chodzko et al. (1991) and Lecompte et al. (1996) on black marls at the Séderon site $\left(30 \mathrm{~mm}\right.$ year $\left.{ }^{-1}\right)$. That is probably due to specific local factors, or to problems of the measuring devices.

As far as the influence of two site-specific factors - the exposure and the dip-slope angle, are concerned, the following points must be emphasized:

- the dip-slope angle seems to be a site-specific factor which explains the rates of soil loss (Descroix, 1994). Values are three times higher when slope and dip are approximately perpendicular $\left(9.3 \mathrm{~mm} \mathrm{year}^{-1}\right)$ than when they are almost parallel $\left(3.3 \mathrm{~mm}\right.$ year $\left.^{-1}\right)$.

- erosion is greater on north-facing slopes with a high dip-slope angle; in contrast, it has lower values on the south-facing hillslopes where dip and slope are parallel. A north-facing slope with low dip-slope angle has not been encountered on the experimental sites. In the Seignon catchment (Préalpes de Digne), Rovéra et al. (1999a) measured the same erosion depth $\left(5 \mathrm{~mm}\right.$ year $\left.^{-1}\right)$ on both south-facing slopes with a high dip-slope angle and north-facing slope with dip-slope parallelism.

It should be noted that the dip and slope in badlands are mostly orthogonal due to their geomorphological context. In fact, most of the badlands are exposed by anticlinal folds, beneath the "tithonic" limestone. The erosion along the anticlinal hinge results in this final configuration with hillslopes cutting the bedding at high angles (Fig. 3).

Once the equilibrium profile has been reached, the hillslope gradient of badlands remains constant. Thus, there is an annual balance: the bottoms of gullies are excavated at the same rate at which interfluves and slopes are eroded. This process ends when gully excavation reaches a hard limestone layer. Thereafter, sediment accumulation fills the bottom of the gullies, and slope angles decrease. This configuration is widespread on blue marls, which are thinner and homogeneous than the OxfordoCallovian black marls. Moreover, the blue marl units being younger, they usually outcrop in synclines while the "terres noires" are exposed in anticlines, as previously mentioned.

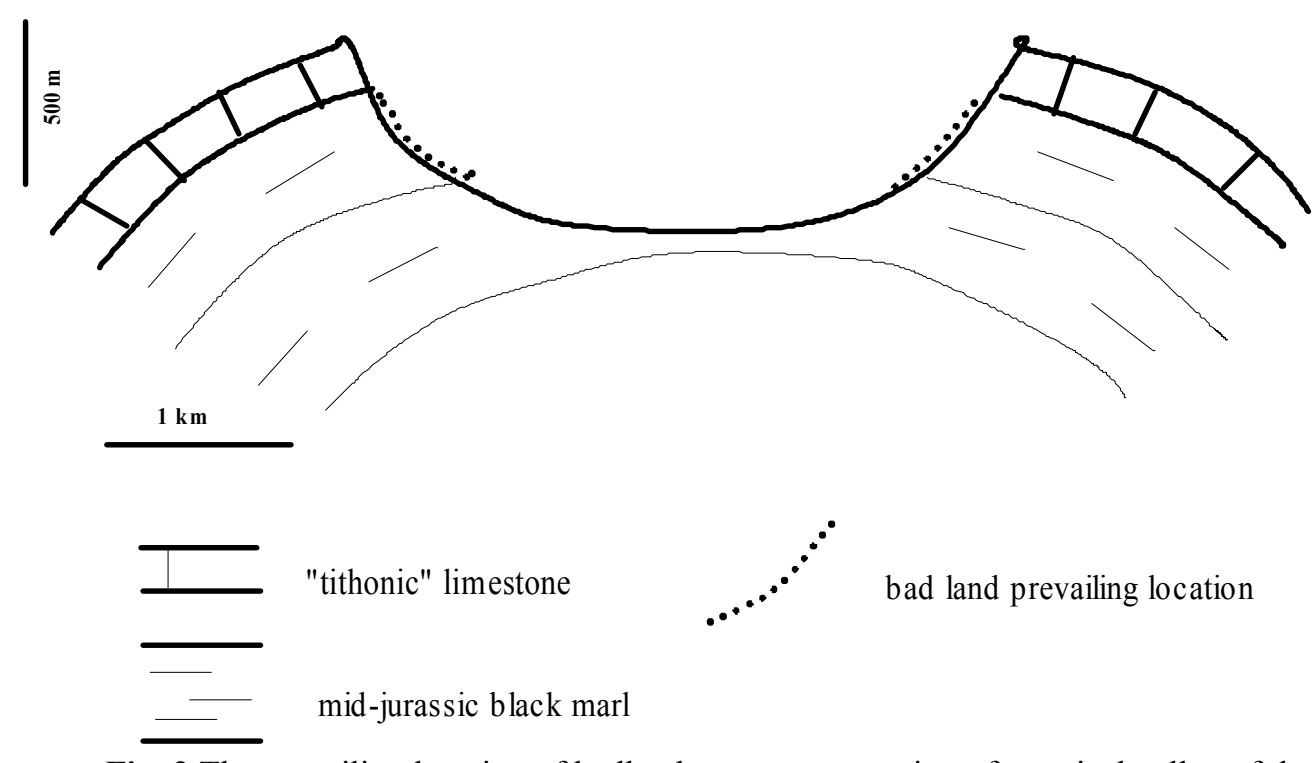

Fig. 3 The prevailing location of badlands on a cross section of a typical valley of the "Vocontian Graben" badlands are mostly located where the slope gradient and the intensity of overland flow are high. This explains why the dip-hillslope angle is commonly between 60 and $90 \%$. 


\section{Temporal factors}

Freeze-thaw and wet-dry cycles The simulation of 100 freeze-thaw cycles with a wet-dry cycle every seven days gave conclusive results in a short time: marl samples of the Oxfordo-Callovian black marls were entirely disaggregated and those of the Cenomanian blue marls were disaggregated by $40 \%$. After 200 cycles, both marls were completely weathered and none of the remaining particles were larger than $1 \mathrm{~cm}$ long. The annual number of freeze days in the southern French Alps ranges between 80 and 160 , but a thaw occurs almost daily during winter; the annual number of thawless days (temperature remains below $0^{\circ}$ all day long) varies from 2 to 60 , depending on altitude. Samples of "tithonic" limestone of the same size $(7 \mathrm{~cm}$ edge cubes) submitted to the same treatment lost less than $0.1 \%$ of their initial weight.

Soil moisture It is assumed that the main erosion agent is water. As the regolith layer of the badlands is completely bare, its water depletion time is very short. Therefore, it probably has a Hortonian behaviour and the previous water content of the superficial layer is a determining factor for the appearance of infiltration excess runoff, and thus for sediment yield.

The relationships between observed runoff and rainfall, between calculated runoff and rainfall, and between calculated and observed runoff, for plot 4 are presented in Fig. 4 (a), (b) and (c), respectively.

Analysis of four plots, therein plot 1 being entirely vegetated (dense Graminaceae cover), and the other three completely bare, leads to the following observations:

- in the vegetated plot, an API-type model is not applicable, because of a nonHortonian functioning of the soil. Runoff depth values are very low and, despite the 220 rainy measurements, only nine significant runoff measurements were recorded. Furthermore, the rainfall-runoff correlation is extremely poor $\left(r_{1}^{2}=0.002\right)$.

- $\quad$ in the other three plots, significant rainfall-runoff relationships $\left(r_{2}^{2}\right.$ value of 0.54 0.96) can be obtained using the API-type model. The use of the model led to an increase in the coefficient of determination by an average of 0.33 .

- the runoff coefficient on badlands ranges between 0.2 and 0.36 . Plot 2 is the only stony plot (30\% of rock fragment cover), which explains its weak runoff coefficient (Descroix et al., 2001). The kinetic energy of rain drops is absorbed by rock fragments and this results in an increased infiltration rate.

- the parameter $\alpha$ ranges from 0.1 to 0.2 , in agreement with values obtained in the mountains of northern Mexico, where soils are also very thin $(0-60 \mathrm{~cm}$ with a mean value of $20 \mathrm{~cm}$ ) (Viramontes, 2000; Descroix et al., in press).

Rainfall amount and rainfall kinetic energy It is well known that rainfall is the most important erosion and transport agent in badlands. The detachment of particles is caused in the cold season by the climatic cycles; the transportation down the hillslopes and out of the catchments is firstly supplied by overland flow (Olivry et al., 1988; Bufalo, 1989; Olivry \& Hoorelbeck, 1990; Descroix, 1994; Lecompte et al., 1998).

The simplest rainfall-soil loss relationship is:

$$
S L=a P
$$

where $S L$ is the soil loss $\left(\mathrm{mm}\right.$ year $\left.^{-1}\right)$ and $P$ is the rainfall $(\mathrm{mm})$. On the black marl 
(a)

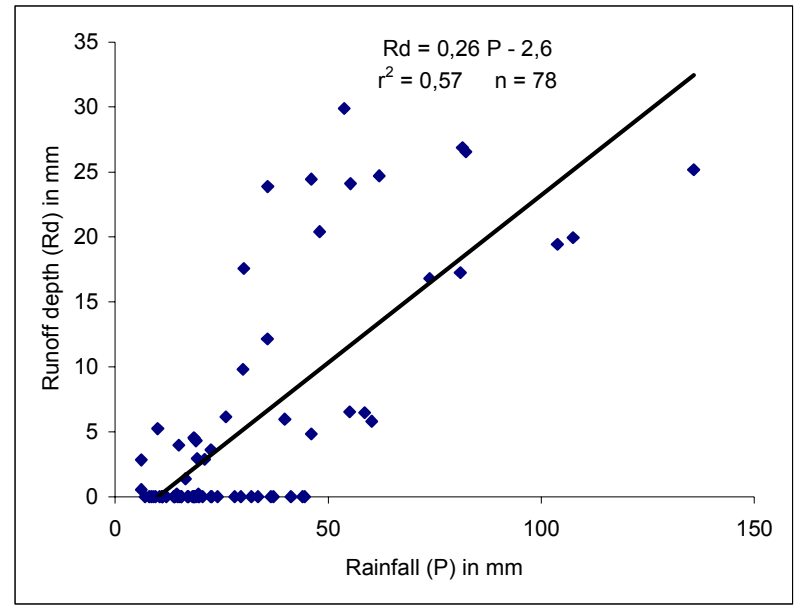

(b)

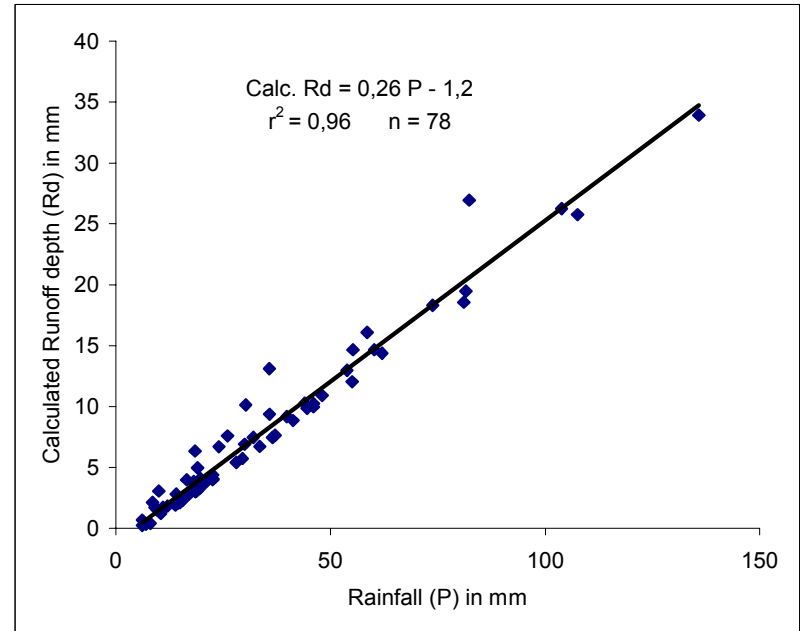

(c)

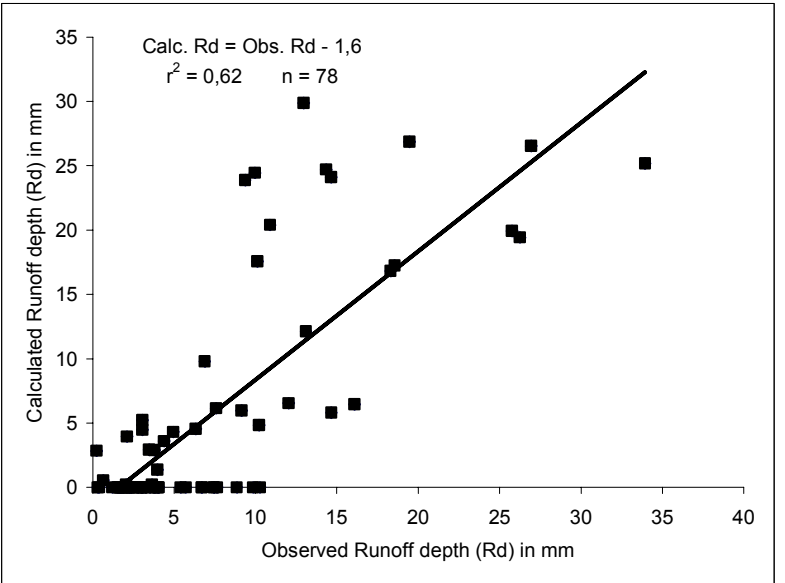

Fig. 4 Rainfall-runoff relationship (a) observed and (b) calculated by the Nazas model, for plot no. 4 (black marls, Orpierre site); and (c) the relationship between calculated and observed runoff depth for the same plot.

badlands, the value of coefficient $a$ is 5.6-8.9 for a mean annual rainfall amount of $900 \mathrm{~mm}$. The coefficient of determination (squared correlation coefficient) is low: between 0.28 and 0.42 , depending on the plots. This is due to the variation in rainfall conditions; along with the previous soil moisture, the rainfall intensity, effective 
Table 1 Coefficient of determination of the $S L=a K E+b$ relationship for all plots located in black marls.

\begin{tabular}{cclll}
\hline Plot & $a$ & $r^{2}$ & Number of observations & Slope $\left(^{\circ}\right)$ \\
\hline 1 & $0.0036^{*}$ & 0.86 & 35 & 18 \\
2 & 10.3 & 0.82 & 51 & 25 \\
3 & 11.2 & 0.69 & 59 & 30 \\
4 & 3.3 & 0.69 & 45 & 48 \\
5 & 3.8 & 0.57 & 26 & 36 \\
6 & 4.9 & 0.06 & 14 & 26 \\
7 & 6.3 & 0.7 & 11 & 28 \\
12 & 11.1 & 0.87 & 12 & 36 \\
13 & 1.8 & 0.88 & 10 & 28 \\
14 & 5.6 & 0.56 & 11 & 35 \\
15 & 5 & 0.57 & 8 & 33 \\
16 & 8 & 0.75 & 9 & 32 \\
17 & 1.5 & 0.95 & 7 & 30 \\
\hline
\end{tabular}

* this plot is completely vegetated.

$S L=$ soil loss in mm year ${ }^{-1} ; K E=$ kinetic energy of rainfall in $\mathrm{J} \mathrm{m}^{-2} \mathrm{~mm}^{-1}$.

rainfall and kinetic energy of rain are the more commonly assumed parameters explaining soil erosion (Descroix, 1994) in sub-Mediterranean mountains such as the southern French Alps.

The kinetic energy of rainfall appears to function as an adequate approximation for rainfall amount, rainfall intensity and effective rainfall. Hence the simple relationship:

$$
S L=a K E
$$

where $K E$ is kinetic energy $\left(\mathrm{J} \mathrm{m}^{-2}\right)$ is assumed to be the best equation to explain soil losses. As shown in Table 1, the value of coefficient $a$ ranges from 1.5 to 11 for badlands. Of the results obtained for 13 different plots (six of the 19 micro-plots are not located on marls), eight of them have determination coefficients above 0.68 ; only two have $r^{2}$ below 0.55 .

\section{DISCUSSION}

A general agreement appears to exist on the annual erosion depth in badlands consisting of marls; the data concerning the rates of soil loss given in other papers are obtained using different materials and methods and in source areas ranging from $1 \mathrm{~m}^{2}$ to several $\mathrm{km}^{2}$; soil losses generally vary between 6 and $12 \mathrm{~mm} \mathrm{year}^{-1}$.

These values are observed irrespective of the catchment size; thus, at the Savournon experimental site, considering only the eroded areas, erosion depth has similar values in a 7.8 ha catchment $\left(8.3 \mathrm{~mm} \mathrm{year}^{-1}\right)$ to a 75 ha one $\left(8.1 \mathrm{~mm}^{-1 e a r^{-1}}\right)$ (Olivry \& Hoorelbeck, 1990). Likewise, in the Seignon catchment, there is no reduction in measured soil loss rates when the area concerned increases. Considering that sediments which filled a small reservoir had their source in eroded areas, Combes (1981) estimated that annual erosion depth on marl badlands was $6.8 \mathrm{~mm}_{\text {year }}{ }^{-1}$ over 18 years. On plots located in the same catchment, Rovera et al. (1999b) measured rates of between 4 and $10 \mathrm{~mm} \mathrm{year}^{-1}$. Likewise, Bufalo (1989) observed in microcatchments of between 200 and $2000 \mathrm{~m}^{2}$ that the size of the basin did not influence the erosion rate. However, these observations have always been made over a period of at 
least one year. At the catchment scale, it is necessary to consider the formation of detached material on hillslopes during the winter and the transportation out of the catchment by rainfall events during the two main annual transport periods: the spring, on the one hand and the end of the summer and the beginning of the autumn when rainfall intensities are higher, on the other.

The solifluction phenomena have not been discussed herein; the constant flow of the regolith layer down the slopes due to climatic cycles was calculated by Descroix (1994) as representing a shift of $30 \mathrm{~mm}$ year $^{-1}$ in the direction of the slope. If it is assumed that half the thickness of regolith $(30 \mathrm{~mm})$ is moving, the erosion depth due to these phenomena can be estimated as $0.4 \mathrm{~mm}_{\text {year }}{ }^{-1}$. It is significant, but is small in comparison to the erosion by water.

The main remaining items to be treated concern the influence of both exposure and dip-slope angle on sediment formation in the degraded areas.

The differences between north- and south-facing hillslopes and between high and low dip-slope angle can be explained by the roles of temperature and infiltration. Different impacts of temperature, depending on the exposure, were determined by Oostwoud Widjenes \& Ergenzinger (1997). They noticed in Draix that, during the year, distinct erosion processes were triggered according to the occurrence or absence of freeze-thaw cycles. The same observation was made by Rovera \& Robert (personal communication) in the Seignon catchment; in a new experiment in Draix, these latter authors equipped a north-facing and a south-facing hillslope in order to determine precisely the role of these micro-climates.

The homogeneity of the erosion depth data is due to the combination of all site factors, which are synthesised at the outlet of a catchment. The sediment yield seems to be the same whatever the considered area, if the following conditions are verified:

- the whole year processes are taken into account;

- all the exposure and dip configurations are considered;

- in case of measurement at the catchment outlet, the sediment yield is attributed only to previously degraded areas.

This set of conditions explains the general agreement concerning the erosion depth of marl badlands.

\section{CONCLUSIONS}

The marly badlands are known to be the most significant sediment supplier in the southern French Alps. The marl outcrops cover more than $3500 \mathrm{~km}^{2}$, mainly in the Durance River middle basin. Depending on the areas, badlands represent between 5 and $30 \%$ of the total outcrops.

There is a general consensus that the erosion depth in marls is around $1 \mathrm{~cm}_{\text {year }}{ }^{-1}$. This rate characterizes all local configurations, and it was measured at both plot and catchment scales, at several sites and using different materials and methods.

The main factor which influences erosion by water is the rainfall amount, but the kinetic energy of a rainfall event was found to be a more adequate variable, because it integrates the role of both the intensity and the total amount of the rainfall. The second main variable was determined as the previous soil water content; the antecedent precipitation index $(A P I)$ was used in this case as a palliative for the absence of soil moisture data. 
Spatial variables were studied considering that vegetation and slope do not change (absence of vegetation, and badlands slopes of $30-40^{\circ}$ ). Consequently, it was possible to determine a contrast between north- and south-facing hillslopes in terms of erosion processes and erosion depth values. North-facing hillslopes appeared to be more subject to the effects of periglacial processes and sediment yield was greater on these slopes. In the same way, the dip-slope angle appeared to have a strong influence. For high values of this angle, climatic cycles have a higher impact on the detachment of particles than when dip and slope are nearly parallel.

\section{REFERENCES}

Artru, P. (1972) Les terres noires du bassin rhôdanien (bajocien supérieur à oxfordien moyen), stratigraphie, sédimentologie, géochimie. Thèse de l'Université Claude Bernard-Lyon I, France.

Birot, P. (1981) Les processus d'érosion à la surface des continents. Masson, Paris, France.

Blijenberg, H. M., De Graaf, P. J., Hendricks, M. R., De Ruiter, J. F. \& Van Tetering, A. A. A. (1996) Investigation of infiltration characteristics and debris flow initiation conditions in debris flow source areas using a rainfall simulator. Hydrol. Processes 10, 1527-1543.

Brochot, S. \& Meunier, M. (1995) Erosion des bad-lands dans les Alpes du Sud. Synthèse. Compte rendu de recherches no. 3, BVRE de Draix. Editions du Cemagref, Antony, France, coll. Etudes, 21,141-174

Bufalo, M. (1989) L'érosion des terres noires dans la région du Buëch (Hautes-Alpes, France). Thèse de Géologie, Université Aix-Marseille III, France.

Burwell, R. E., Allmaras, R. R. \& Amemiya, M. (1963) A field measurement of total porosity and surface microrelief of soils. Soil. Sci. Soc. Am. Proc. 27, 697-700.

Cemagref (1987) Bassins-versants expérimentaux de Draix. Compte rendu de recherche no. 1 en érosion et hydraulique torrentielle, Cemagref, Grenoble, France.

Cemagref (1995) Bassins-versants expérimentaux de Draix. Compte rendu de recherche no. 3, Cemagref, Grenoble, France.

Cemagref (1997) Les bassins versants expérimentaux de Draix, laboratoire d'étude de l'érosion en montagne. (Experimental catchments of Draix: a field laboratory for mountains erosion studies). Actes du Colloque de Digne, Cemagref, France.

Chodzko, J., Lecompte, M., Lhénaff, R. \& Marre, A. (1991) Vitesse de l'érosion dans les roubines des Baronnies (Drôme). Physio-Géo 22-23, 21-28.

Cohen, M. (1998) Végétation et ravinement dans les Baronnies méridionales (Alpes françaises). Géomorphologie : relief, processus, environnement 1, 35-52.

Combes, F. (1981) Le barrage du Seignon, un exemple de sédimentation. In: La Gestion Régionale des Sédiments (Actes du Colloque de Propriano, Corse). Doc. du BRGM no. 30, 101-104. Bureau de Recherches Géologiques et Minières (BRGM), Orléans, France.

Coubat, M. (1998) Rôle des processus périglaciaires et nivaux dans l'érosion des marnes noires en milieu subméditérranéen reboisé: l'exemple du bassin versant du Saignon. Travail d'étude et de recherche, Institut de Géographie Alpine, Grenoble, France.

Delannoy, J.-J. \& Rovéra, G. (1996) L'érosion dans les Alpes occidentales: contribution à un bilan des mesures et des méthodes. Rev. Géogr. Alpine 84(2), 87-101.

Descroix, L. (1985) Contribution à l'étude de la dynamique érosive dans les Baronnies Occidentales et les Pays du Buëch Moyen: problèmes d'aménagement. Thèse de IIIème cycle de géographie, Université Lyon II, France.

Descroix, L. (1994) L'érosion actuelle dans la partie occidentale des Alpes du Sud. Thèse de doctorat de géographie, Université Lyon II, France.

Descroix, L., Nouvelot, J. F. \& Vauclin, M. (in press) The role of the Antecedent Precipitation Index on runoff functions: applications to the Sierra Madre Occidental (North-western Mexico). J. of Hydrol.

Descroix, L., Viramontes, D., Vauclin, M., Gonzalez Barrios, J. L. \& Esteves, M. (2001) Influence of surface features and vegetation on runoff and soil erosion in the western Sierra Madre (Durango, North West Mexico). Catena 43, 115135.

Deshons, P. (1985) Bassins-versants expérimentaux en Haute-Provence: problèmes d'érosion et cadre climatologique. Mémoire de DEA, Université de Montpellier, France.

Kohler, M. A. \& Linsley, R. K. (1951) Predicting the runoff from storm rainfall. Research Paper no. 34, US Weather Bureau, US Dept of Commerce., Washington DC, USA.

Lecompte, M., Lhénaff, R., Marre, A. (1996) Premier bilan de six années de mesure sur l'ablation dans les roubines des Baronnies méridionales (Préalpes Françaises du Sud). Rev. Géogr. Alpine 84(2), 11-16.

Lecompte, M., Lhénaff, R. \& Marre, A. (1998) Huit ans de mesure du ravinement des marnes dans les Baronnies méridionales (Préalpes Françaises du Sud). Géomorphol. 4, 351-374.

Lhénaff, R., Coulmeau, P., Lecompte, M. \& Marre, A. (1993) Erosion and transport processes on badlands slopes in the Baronnies mountains (French Southern Alps). Geografía Física e Dinámica Quaternaria 16, 65-73.

Lukey, B. T., Sheffield, J., Bathurst, J. C., Hiley, R. A. \& Mathys, N. (2000) Test of the SHETRAN technology for modelling the impact of reforestation on badlands runoff and sediment yield at Draix, France. J. Hydrol. $235,44-62$. 
Malet, J. P., Maquaire, O. \& Klotz, S. (2000) The Super-Sauze flowslide (Alpes de Haute-Provence, France): triggering mechanisms and behaviour. In: Proc. Eighth Int. Symp. on Landslides (Cardiff), vol. 2, 999-1006. T. Telford, UK.

Mathys, N., Brochot, S.\& Meunier, M. (1996) L'érosion des terres noires dans les Alpes du Sud: contribution à l'estimation des valeurs annuelles moyennes (bassins-versants expérimentaux de Draix, Alpes de Haute-Provence, France). Rev. Géogr. Alpine 84(2), 17-28.

Olivry, J.-C. \& Hoorelbeck, J. (1990) Erodibilité des terres noires de la vallée du Buëch. Cah. ORSTOM, Pédologie 25(1-2), 95-110.

Olivry, J.-C., Quelennec, R. E., Hoorelbeck, J. \& Bufalo, M. (1988) Erosion des terres noires de la vallée du Buëch (Alpes du Sud). Groupement d'études BRGM-Orstom, Montpellier, France.

Oostwoud Widjenes, D. J. \& Ergenzinger, P. (1997) Rainfall simulations and soil temperature measurements at steep marly slopes in the Draix Experimental Research basin. Actes du colloque "Experimental Catchments of Draix: $a$ field laboratory for mountains erosion studies", Digne, France, 22-24/10/1997, Ed. Du Cemagref, Antony, France, p. $143-154$.

Oostwoud Widjenes, D. J. \& Ergenzinger, P. (1998) Erosion and sediment transport on steep marly hillslopes, Draix, Haute-Provence, France: an experimental field study. Catena 33, 179-200.

Peyronnet, J. (1988) Caractérisation de l'érosion dans les zones sensibles des Alpes du Sud. Mémoire de DEA National d'Hydrologie, Université de Montpellier-Orstom, France.

RGA (Revue de Géographie Alpine) (1996) Special Issue: Les processus d'érosion en milieu montagnard. Bilan et méthodes. Rev. Géogr. Alpine 84(2). Grenoble, France.

Robert, Y. (1997) Erosion et colonisation végétale dans les bad-lands marneux des Alpes du Sud, l'exemple du bassin versant du Saignon. Travail d'étude et de recherche, Institut de Géographie Alpine, Grenoble, France.

Rovera, G., Robert, Y. \& Coubat, M. (1999a). L'action des processus périglaciaires dans les badlands marneux des Alpes du Sud: l'exemple du bassin-versant du Saignon. Environnements Périglaciaires 6, 41-52. Association Française du Périglaciaire.

Rovera, G., Robert, Y., Coubat, M. \& Nedjai, R. (1999b) Erosion et stades biorhexistasiques dans les ravines du Saignon. Essai de modélisation statistique des vitesses d'érosion sur marnes. Actes du Colloque La montagne méditerranéenne (Aix en Provence, 8-10 octobre 1998). Et. Géogr. Phys. no. XXVIII.

Schmutz, M, Guérin, R., Schott, J. J., Maquaire, O., Descloitres, M. \& Albouy, Y. (2000) Geophysical method contribution to the Super-Sauze (South France) flowslide knowledge. In: In: Proc. Eighth Int. Symp. on Landslides (Cardiff), vol. 3, 1234-1240. T. Telford, UK.

Viramontes, D. (2000) Comportement hydrodynamique des milieux dans le Haut bassin du rio Nazas (Sierra Madre Occidentale, Mexique); causes et conséquences de leur évolution. Thèse de Doctorat de l’Université Joseph Fourier, Grenoble, France.

\section{Received 21 February 2001; accepted 15 October 2001}

